\title{
Inadequate Health Literacy and the Role of Cyberspace in the Tendency to Use Alcohol in the Prevention of Coronavirus
}

\author{
Mojtaba Fattahi Ardakani (iD) ${ }^{1,{ }^{*}}$ and Ahmad Sotoudeh ${ }^{2}$ \\ ${ }^{1}$ Diabetes Research Center, Shahid Sadoughi University of Medical Sciences, Yazd, IR Iran \\ ${ }^{2}$ Department of Health Education and Health Promotion, School of Public Health, Bushehr University of Medical Sciences, Bushehr, IR Iran \\ "Corresponding author: Diabetes Research Center, Shahid Sadughi University of Medical Science, Yazd, IR Iran. Email: mjfattahi57@gmail.com \\ Received 2020 June 21; Revised 2020 October 23; Accepted 2020 December 12.
}

Keywords: Health Literacy, Alcohol Drinking, Coronavirus

\section{Dear Editor,}

The World Health Organization has defined health literacy as " cognitive and social skills that form the motivation and ability to access, understand, and use of knowledge in ways that promote and sustain good health"(1). People are always engaged with challenges regarding making decisions to bring about change in their lives and their health. Low or limited health literacy affects the ability of individuals to search for and use of knowledge, adopting healthier habits, and being prepared for public health emergencies. Limited health literacy is associated with poorer health outcomes and higher health expenditures (2). As the widespread of false information has blurred the lines between what is true or false, seeking valid and reliable information is of crucial importance, which indicates the importance of evaluating information (3). The internet is an open door to both valid and misleading information. Several studies have reported low levels of health literacy among Iranians (4-6). The first case of Covid-19 infection was officially announced at the beginning of 2020 . Internet, also named cyberspace, is a common source of information, mainly through social media. Covid-19 has infected tens of thousands of Iranians and claimed many lives (7).

Unfortunately, conflicting information has resulted in misunderstandings about the Covid-19 in Iran. As a result, lack of access to valid information has caused several difficulties, similar to what happened regarding drinking alcohol (8). More than 100 cases are died due to alcohol poisoning $(9,10)$. The media provides information on the prevention of Covid-19 that may also contain invalid information. Therefore, a number of people in the community are not able to distinguish valid information from false (11). Often, invalid information related to cyberspase. Therefore, not evaluating information can be attributed to low health literacy $(12,13)$.

In conclusion, sufficient health literacy is a real need. Thus, more so cyberspace is vital. In most of the developed countries, all citizens have a family physician (11), who provides them with valid information. In our country, Iran, health care providers can take on this role. Dissemination of accurate information is a crucial step for promoting the health literacy of societies, particularly through cyberspace. Thus, take-home messages can clarify accurate information that increase the tendency to healthy behaviors.

Although health literacy is a major contributor to improved health, according to the best knowledge of the authors, no study has investigated the association between health literacy and alcohol consumption. Hence, further studies are required.

\section{Footnotes}

Authors' Contribution: Mojtaba Fattahi Ardakani designed and directed the project. All authors contributed to the implementation of the research and the final manuscript.

Conflict of Interests: The authors declare no conflict of interest.

Funding/Support: There is no funding support.

\section{References}

1. Nutbeam D. Health promotion glossary. Health Promot Int. 1998;13(4):349-64. doi: 10.1093/heapro/13.4.349.

2. Adams RJ, Stocks NP, Wilson DH, Hill CL, Gravier S, Kickbusch I, et al. Health literacy-a new concept for general practice? Aust Fam Physician. 2009;38(3):144-7. [PubMed: 19283256]. 
3. Seo HM, Hah YS. [A study of factors influencing on health promoting lifestyle in the elderly-application of Pender's health promotion model]. Taehan Kanho Hakhoe Chi. 2004;34(7):1288-97. doi: 10.4040/jkan.2004.34.7.1288. [PubMed: 15687769].

4. Paakkari L, Okan O. COVID-19: health literacy is an underestimated problem. Lancet Public Health. 2020;5(5):e249-50. doi: 10.1016/s24682667(20)30086-4.

5. Haghdoost AA, Karamouzian M, Jamshidi E, Sharifi H, Rakhshani F, Mashayekhi N, et al. Health literacy among Iranian adults: findings from a nationwide population-based survey in 2015. East Mediterr Health J. 2019;25(11):828-36. doi: 10.26719/emhj.19.017. [PubMed: 31782520].

6. Dadipoor S, Ramezankhani A, Aghamolaei T, Rakhshani F, SafariMoradabadi A. Evaluation of health literacy in the Iranian population. Health Scope. 2018;In Press(In Press). doi: 10.5812/jhealthscope.62212.

7. Abdi M. Coronavirus disease 2019 (COVID-19) outbreak in Iran: Actions and problems. Infect Control Hosp Epidemiol. 2020;41(6):7545. doi: 10.1017/ice.2020.86. [PubMed: 32192541]. [PubMed Central: PMC7137533].

8. Sudore RL, Mehta KM, Simonsick EM, Harris TB, Newman AB, Satterfield $S$, et al. Limited literacy in older people and disparities in health and healthcare access. J Am Geriatr Soc. 2006;54(5):770-6. doi: 10.1111/j.1532-5415.2006.00691.x. [PubMed: 16696742].

9. Delirrad M, Mohammadi AB. New methanol poisoning outbreaks in Iran following COVID-19 pandemic. Alcohol Alcohol. 2020;55(4):347-8 doi: 10.1093/alcalc/agaa036. [PubMed: 32400874]. [PubMed Central: PMC7239215].

10. Li C, Chen LJ, Chen X, Zhang M, Pang CP, Chen H. Retrospective analysis of the possibility of predicting the COVID-19 outbreak from Internet searches and social media data, China, 2020. Euro Surveill. 2020;25(10). doi: 10.2807/1560-7917.ES.2020.25.10.2000199. [PubMed: 32183935]. [PubMed Central: PMC7078825].

11. Epstein JB, Gorsky M, Cabay RJ, Day T, Gonsalves W. Screening for and diagnosis of oral premalignant lesions and oropharyngeal squamous cell carcinoma: role of primary care physicians. Can Fam Physician. 2008;54(6):870-5. [PubMed: 18556495]. [PubMed Central: PMC2426981].

12. Sunday Times. Tractors and vodka will cure Belarus of the coronavirus, says leader. 2020, [cited 5 May]. Available from: https://www.thetimes.co.uk/article/tractors-and-vodka-will-curebelarus-of-the-coronavirus-says-leader-t6b9xvc55.

13. Radio Free Europe. Coronavirus vs. The church: Orthodox traditionalists stand behind the holy spoon. 2020, [cited 5 May]. Available from: https://www.rferl.org/a/coronavirus-vs-the-church-orthodoxtraditionalists-stand-behind-the-holy-spoon/30492749.html. 